\title{
A FAMÍLIA MULTIGERACIONAL E SEUS PERSONAGENS
}

\author{
Alda Britto da MotTA*
}

RESUMO: O objetivo deste artigo é discutir, a partir dos resultados de quatro pesquisas realizadas ao longo desta década, na Bahia, a família multigeracional contemporânea em dois dos seus segmentos geracionais básicos: os muito idosos, que crescentemente atingem a condição de centenários, e a geração-pivô, constituída por seus filhos, também idosos, que, além de se constituírem em seus cuidadores, também apoiam os seus próprios filhos e netos. Para isso será necessário abordar a questão da duplicidade dos papéis geracionais como obrigatoriamente de gênero, contemplando, ao mesmo tempo, mudanças: o processo de ressocialização desses "idosos jovens", os quais, participando de novas experiências, como lazer em grupo ou retorno ao mercado de trabalho, tentam novas atuações sociais.

Palavras-chave: Geraçōes. Socialização. Relações de gênero.

\section{MulTigenERATIONAL FAMILIES AND THEIR PERSONAGES}

ABSTRACT: Based on the results of four surveys conducted during the past 10 years, in Bahia, this paper explores two basic generations of contemporary multigenerational families: the very old, who are increasingly becoming centenarians, and the pivot generation, constituted by their children, who also grow older. Besides being caregivers for the former, the latter frequently support their own children and grandchildren. We thus consider the duplicity of the generational roles as gender-oriented and take

Doutora em Educação e professora do Departamento de Sociologia e da Faculdade de Filosofia e Ciências Humanas da Universidade Federal da Bahia (UfBA). E-mail: aldamotta01@hotmail.com 
into account the impact of social changes on the resocialization process of the "young old" who, after new experiences such as leisure groups or return to the labor market, are trying to play new social roles.

Key words: Generations. Socialization. Gender relations.

\section{Introdução}

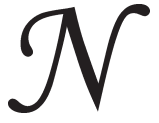

o percurso teórico e no descortino atual das idades e relaçóes socialmente fundamentais, vêm-se destacando as famílias multigeracionais como loci privilegiados destas, na sua estrutura destacando-se dois segmentos populacionais muito nítidos, ao mesmo tempo quase ignorados pela pesquisa no Brasil, e que pela sua novidade de realização e intensidade quali-quantitativa se constituem em expressivos personagens geracionais, demandando pesquisa urgente: os centenários e a geração-pivô.

A geração intermediária ou pivô foi socializada pelas gerações mais antigas, principalmente a dos seus pais centenários, para o exercício dos papéis tradicionais, sobretudo de gênero - os homens, como provedores; as mulheres, para serem essencialmente cuidadoras. Mas ao mesmo tempo estão vivenciando agora outros processos sociais e extrafamiliares do mundo capitalista, que os redirecionam ou ressocializam para novas atuações.

E de tal forma vêm-se diferenciando os segmentos geracionais mais velhos, que já não são simplesmente “idosos", mas fazem jus a novas denominações, tais como "idosos jovens" e "muito idosos" ou "velhos mais velhos". E seu cotidiano, ainda quando moram juntos, é também muito diferenciado - principalmente (importante questão de gênero) quando se observam as mulheres. Assim é que as geraçôes mais velhas se conservam ou se voltam para a vida privada - literal ou simbolicamente aposentados conforme sejam homens ou mulheres -, mantendo laços de sociabilidade tradicional; ao passo que os idosos “jovens" estão sendo ressocializados em direção à naturalidade (mas também necessidade crescente), de participação das mulheres no mercado de trabalho, e dos homens em inicial partilha de algumas das antigamente só "femininas" tarefas domésticas. E, importante, rendendo-se alegremente as mulheres ao apelo ou à atração de uma 
sociabilidade nova dos grupos e "programas para a terceira idade". E, mais, novíssimo e tentativamente, para atividades políticas no movimento dos aposentados, embora este ainda seja majoritariamente constituído por homens.

\section{A família multigeracional}

A reconhecida heterogeneidade do segmento idoso da sociedade cresce com o atual e continuado aumento da longevidade, estendendo-se ao interior da própria condição geracional. Isso significa que, além das diversidades de gênero, de classe social e de raça, articuladamente presentes no interior dos diferentes grupos etários idosos (Britto da Motta, 1999a), assim definidos, para os países "em desenvolvimento", a partir dos 60 anos, vem-se destacando uma sequência outra de diferenciaçôes, de ordem diretamente etária/geracional, entre idosos “jovens" e "velhos mais velhos". E, como se não bastasse a existência de um intervalo etário muito grande em extensão, de cerca de 40 anos, no segmento idoso, vai-se prolongando este ainda mais, formando outro grupo populacional ainda mais velho - o dos centenários.

Em contrapartida, estende-se tanto, hoje, o estrato geracional idoso, com as características tradicionalmente imputadas à "velhice" sendo afastadas para mais adiante no tempo, para uma idade mais avançada (velhos mais velhos), ao passo que os menos idosos são cada vez mais “jovens” (Britto da Motta, 2006a), que é de se perguntar até que ponto os atuais indivíduos de 60 e 70 anos ainda poderão ser considerados "velhos" pelos padróes atuais.

Porque tão diferentes quanto são, quantitativamente, as idades de 60, 80 ou 100 e mais anos, podem, evidentemente, ser as condições corporais, sociais e os modos de vida de cada grupo dessas pessoas. Além de terem nascido em momentos sociais diversos e, consequentemente, formado seus habitus de classe e, conforme o gênero e a geração, em condiçỗes ou tempos sociais diferentes (Bourdieu, 1990; Britto da Motta, 1999a), têm variados tempos de experiência de vida, e de uso e desgaste corporal e afetivo/emocional, ao confluírem para a atualidade. Com o que vivem uma contemporaneidade relativa, pois, como apontou Mannheim ([19-], p. 124), o "mesmo tempo" não é igual para todos: "Todas as pessoas convivem com pessoas da mesma e 
de diferentes idades (...). Mas para cada uma o 'mesmo tempo' é um tempo diferente (...)".

Pois até mesmo para as gerações idosas o tempo de formação foi e está sendo cada vez mais diversificado, assim como as vivências e a própria extensão do percurso de vida já vencido. $\mathrm{O}$ que as pesquisas atuais começam a levantar e precisam aprofundar. Revelar o jogo desigual das relações entre as gerações, tanto em sua trajetória social como na pessoal, cotidiana, e incluir aquelas pouco estudadas, como algumas intermediárias (pivôs) e as "finais" (centenários), para completar o cenário social e particularmente o desse fenômeno único da contemporaneidade, a família multigeracional.

Voltando a atenção aos muito velhos, detenho-me com foco especial sobre os centenários, e até mesmo como componente do seu sistema básico de relações - que, sabemos, nessa idade são comumente adstritas à família - (Britto da Motta, 2004), busco identificar a fundamental geração intermediária - ou "pivô" (Attias-Donfut, 1993; Britto da Motta, 2003; Delbes \& Gaymu, 1993) -, constituída pelos filhos dos mais idosos na maturidade ou envelhecendo, com vivências inéditas na contemporaneidade em atividades e papéis superpostos: $f i$ lhos dos mais velhos, pais de adultos ou adolescentes, divididos entre cuidados e apoios aos pais idosos, mas também a filhos e/ou netos e bisnetos. Esteio dos pais, pelas restrições que a velhice mais avançada enseja ou impõe, e dos filhos e netos, pelas consequências da reestruturação produtiva e dificuldade de inserção no mercado de trabalho, mas também pela instabilidade das atuais relações afetivas, com os retornos à casa dos pais ou as reaproximações entre as gerações após casamentos desfeitos.

Diante do que se impõe importante questão teórica, decorrente da amplitude da presença de tantas e tão diversas geraçôes na atualidade, e segundo a formulaçãa de Mannheim ([19-]): Como estão vivendo essas gerações de contemporâneos, que não são coetâneos, este tempo social? Explicitamente, como estão vivendo esses diferentes personagens geracionais, em suas relações cotidianas, os acontecimentos que se estão desenrolando no contexto social mais amplo?

As pesquisas mais atuais começam a identificar e documentar as diferenças entre segmentos de idosos (Britto da Motta, 2004; Camarano, 2004). Os "idosos jovens" correspondem ao que se inventou e difundiu, 
a partir da década de 1960, como pessoas da "terceira idade" (Lenoir, 1979). Objetos de inumeráveis "programas" socializadores (grupos, clubes, "universidades") e apelos ao consumo (viagens, cosmética "especial", residências), têm sido também os mais atraentes e acessíveis à pesquisa científica - embora não tanto quanto à mídia... - porque estão por toda parte; ao mesmo tempo em que são responsáveis diretos por uma já não tão nova imagem social do idoso como dinâmico, alegre e saudável - sempre regeneradora da figura dos "pobres velhinhos" de um passado ainda pouco distante. São também eles e elas que apresentam o atual ineditismo histórico, particularmente brasileiro, de longa permanência no mercado de trabalho e, sobretudo, de retorno crescente, ainda que pouco formal, a este (Britto da Motta, 2001; Peixoto, 2004; Simões, 2004). Ao mesmo tempo, ou alternativamente, partilham, com os segmentos idosos mais velhos, da condição de beneficiários da Previdência Social, com rendimentos de aposentadoria ou de pensões que, por mais parcos que sejam, propiciam-lhes certa estabilidade financeira, ou melhor, a segurança de uma regularidade de recebimento desse pecúlio que redunda em possibilidade de renovadas relações e contribuiçóes para as suas famílias. Inclusive para os seus jovens, atingidos pela precariedade de emprego ou pelo desemprego estrutural atuais.

Os mais velhos perdem a atração pública e a visibilidade acadêmica na razão direta da sua idade - que se traduz para o público em uma aparência mais desgastada e menor "animação" -, e de maior recolhimento em casa. Embora muitos oitentôes (principalmente oitentonas), e alguns mais raros noventões, permaneçam ativos, saudáveis e participantes de grupos, já não estão circulando muito, nem surpreendendo pela disputa no mercado de trabalho, como os idosos “jovens". Em sua maioria ausentes de festas, bailes e clubes, como espaço público, cultivam uma sociabilidade mais tradicional e restrita, em visitas ou comemoraçôes com antigos amigos e parentes, mas sobretudo em obrigaçôes beneficentes e cerimoniais a ordens religiosas (Britto da Motta, 2004).

Uma vez objetos de pesquisa, encontra-se o óbvio: são os pais e mães dos alegres "terceira idade", como referido, objetos preferenciais ou quase únicos das pesquisas sobre idosos no Brasil. Alegres, mas não raro também pesadamente comprometidos ou onerados com os referidos cuidados e obrigações com pais muito velhos e apoios a filhos e netos, principalmente as mulheres (Britto da Motta, 2003; Delbes \& Gaymu, 
1993). São a geração-"pivô” ou intermediária. Constituem esses dois segmentos os nossos personagens geracionais propostos para análise.

Os centenários constituem atualmente cerca de $1 \%$ da população total do Brasil e um pouco mais na da Bahia. Mais de 70\% residem em área urbana. Guardam, em comum com os outros segmentos idosos, certas características gerais já conhecidas, como maioria de mulheres - e quanto mais avança a idade, maior o contingente feminino -, sendo estas principalmente viúvas e, em bom número (cerca de 16\%), solteiras. Também apresentam nada surpreendente nível baixo de escolaridade. A bibliografia sobre eles é escassa, geralmente na área médica e quase nada no campo das Ciências Sociais. No Brasil, o breve avantpropos de Ana Amélia Camarano (1999), no livro Muito além dos 60, e os estudos prospectivos de Britto da Motta (2006b, 2006c, 2008), que vêm se desenvolvendo a partir de dados de pesquisas. No mais, notícias ou reportagens em revistas e jornais sobre o rápido crescimento demográfico desse segmento, ou sobre datas aniversárias de indivíduos, "surpreendentemente" lúcidos e, não raro, saudáveis nessa faixa etária, instados a revelar o "segredo" para alcançarem essa extraordinária longevidade.

É oportuno ressaltar que, neste artigo, serão discutidos os dados coletados por meio de quatro projetos de pesquisa ("Os velhos mais velhos"; "Relações entre gerações: pais e filhos idosos"; "Relaçōes de gênero e entre geraçôes: pais, filhos e netos"; "Personagens geracionais na família contemporânea: centenários e pivôs”, todos apoiados pelo CNPq), que foram desenvolvidos ao longo desta década - sendo que o último ainda está em andamento -, no estado da Bahia. O objetivo central desses projetos poderia ser definido como a análise das relações entre diferentes gerações familiares, com ênfase sobre o papel das gerações mais velhas.

\section{Centenários e pivôs}

Ao longo de três primeiros projetos de pesquisa com idosos na Bahia, em um total de 104 entrevistados, 20 deles eram centenários: 15 mulheres e 5 homens. Alguns dados relativos a eles foram sistematizados para esta análise. Todos foram objeto de pelo menos uma entrevista em casa, gravada, com toda a circunstância de realização do encontro documentada em diário de campo e algumas vezes em fotografias -, 
porém a maioria deles continuou ou continua acompanhada até hoje, paralelamente ao desenrolar de novos projetos que se debruçam sobre relações entre gerações na família. E no qual grande parte das famílias estudadas foi, justamente, as desses centenários. ${ }^{1}$

$\mathrm{Na}$ premência da identificação etária, não defini previamente como seletivos quaisquer atributos de gênero ou de classe social. Embora, evidentemente, essas categorias estejam necessariamente presentes na análise. Caracterizando esses idosos como grupo de idade, talvez geração, encontrei as seguintes características: oito brancos (1 homem), oito negros (3 homens), quatro pardos (1 homem). Todos se declararam católicos. Nível de instrução relativamente baixo, como é comum encontrar-se em idosos, principalmente nas mulheres. Entretanto essa tendência de gênero não ocorreu entre esses centenários: a escolaridade das mulheres foi mais completa que a dos homens. Oito deles "não estudaram" (3 homens), seis fizeram o primário ( 1 homem) e três o ginásio - primeiro ciclo - (só mulheres). Duas mulheres têm o ciclo secundário completo, a outra o superior (arquiteta). Um homem declarou-se autodidata. Curiosamente, é poeta consagrado, com livros publicados.

Somente sete nasceram em zona rural. Todos moram (ou moravam) em Salvador. À exceção do Sr. Cosme, casado com uma noventona, e de D. Lycia, a arquiteta, solteira, todos são viúvos. Dois moram sozinhos (uma mulher e um homem) e uma mulher mora em asilo há mais de dez anos.

Quatro mulheres e um homem se declararam chefes de família. Os demais - excetuando-se, evidentemente, os três que moram sós ou em asilo - identificaram-se como pai, mãe, avó ou tia da(o) chefe.

Pela condição educacional, laboral e de renda desses centenários, podemos analisar que para a sua "seleção" a "natureza" não se ateve a privilégios de classe... Seis das mulheres nunca trabalharam fora de casa, mas todas, na condição de viúvas, têm pensões. Também contam com pensões ou aposentadorias as que foram: empregada doméstica, lavadeira, professora, deram aulas particulares (uma em cada ocupação) e as três que trabalharam na roça. As três que tiveram o nível mais alto de escolaridade foram, evidentemente, as únicas a se profissionalizar: uma professora primária, uma secretária em tradicional instituição de ensino médio em Salvador e a arquiteta, que teve total entrave, na 
juventude, ao exercício da profissão. Costurou e bordou para se manter, até conseguir trabalhar como funcionária pública; e como tal se aposentou. Os cinco homens foram, respectivamente: lavrador, pedreiro, carpinteiro, biscateiro e funcionário público.

A totalidade dos entrevistados tem renda própria, mas de magnitude muito variável e, em grande parte dos casos, baixa, não raro complementada com alguma ajuda vinda dos filhos, principalmente das filhas (seis casos). Onze dessas pessoas recebem apenas o salário mínimo, e três delas não revelaram seus rendimentos, mas sua condição é visivelmente modesta. A professora recebe um salário mínimo e meio e apenas três mulheres têm rendimentos maiores, entre 6 e 36 salários mínimos.

Apenas sete dos entrevistados são proprietários da casa onde moram - cinco mulheres e dois homens. Os outros moram geralmente em casa de uma filha (sete deles), ou de um filho, da neta, da bisneta ou do sobrinho/filho (um caso cada). Uma vive em asilo e outra mora com a filha em casa alugada, mas ao mesmo tempo tem a renda de uma casa que a idosa aluga.

Variam muito individualmente as condições físicas desses idosos. Como é bastante comum nesse segmento, muitos que têm algum ou alguns problemas de saúde, por sentirem-se emocionalmente bem, declaram ter boas condições de saúde. Suas condições de ânimo alcançam um tom mais para o positivo, na maior parte do tempo. Há queixas, mas também tranquilidade e bom humor. Até D. Etelvina, de 124 anos, a mais velha e mais atingida por deficiências, não chegou a constituir exceção. Quase cega e com grande dificuldade para andar, queixava-se de problemas financeiros, porém também sorria e contava casos. Foi referida pela neta como "a alegria da casa" (Britto da Motta, 2006c).

Ao longo da pesquisa alguns deles morreram. Quase invariavelmente, sem maior extensão de tempo da doença, inclusive D. Etelvina.

Vejamos o perfil e as condiçôes de vida de três desses centenários e uma primeira apresentação de dois pivôs, em sua posição de "sanduíche”.

O mais velho do grupo é Sr. Anísio. Com 108 anos quando da primeira entrevista, caminhava para os 117 anos, quando, há poucos meses, morreu. Nós o acompanhamos durante esses anos, com visitas ocasionais, telefonemas e participação na comemoração de cada um de 
seus aniversários, tudo registrado em diário de campo. Filho de agricultores, trabalhou como pedreiro e tornou-se mestre de obras conhecido em Riachão do Jacuípe, Bahia. Tocava na Filarmônica daquela cidade. $\mathrm{Na}$ festa de seu $115^{\circ}$ aniversário, uma das mais animadas que acompanhei, estava especialmente conversador; em determinado momento foi ao interior da casa buscar uma foto do grupo da Filarmônica, para mostrar a um amigo. A foto passou de mão em mão, entre os mais próximos, enquanto ele contava histórias de alguns daqueles companheiros, todos já falecidos. Sorria gostosamente com uma delas, a do "mistério" do nome do cachorro Jatedigo, de um dos músicos, e encantava uma jovem convidada que, ao seu lado, o escutava, sem perder palavra, sorrindo. Tão encantada ficou que, repetidamente chamada, relutava em ir embora.

Sr. Anísio era negro, de boa altura, porte naturalmente elegante, roupa sempre bem arrumada, tranquilo e atencioso. Saúde só recentemente abalada, com alguma perda auditiva, mas se comunicava bem. As pernas já não eram tão firmes, e na rua era ajudado por uma bengala. Viúvo duas vezes, com 15 filhos, alguns dos mais velhos já falecidos. Comentou certa vez sobre um deles: "Diz o povo que ele está mais velho que eu".

Tinha excelente memória e impressionava a precisão com que referia os fatos, inclusive com datas: "Cheguei de Riachão no dia 8 de agosto de 1961. Cheguei aqui em Salvador - vim pra esta casa em 64”. E por aí se estendia. Era o proprietário da casa, localizada no bairro da Saúde, onde morava, contando com uma empregada para as tarefas domésticas. Responsável pelas próprias despesas, revelou que gostava de morar só. Alguns filhos o ajudavam, financeiramente, mas sem regularidade: "De vez em quando, um dá uma coisa, outro dá outra".

Duas filhas moravam na vizinhança, e uma delas era a grande cuidadora dele: "Anísia me leva pra tudo quanto é canto". Em casa, não gostava de ficar parado: "Faço tudo quanto é coisa (...). Conserto uma coisa, conserto outra”. Não ficava inteiramente só, pois, quando não tinha uma pessoa (empregada) com ele, ia para a casa da filha. Quanto aos parentes, "não tem um que não me dê [bem]". Mantinham contato por telefone.

Tinha poucos amigos pessoais, pois seus compadres estavam quase todos mortos: "Esse é o preço da velhice: a gente perde as pessoas 
da juventude". E revelava: "Eu tenho vontade de ir para a casa dos outros conversar, mas as famílias vão trabalhar, os maridos vão, as mulheres vão trabalhar. O dia de domingo vão pra praia. Pra onde eu vou? Então eu fico em casa". Às vezes recebia alguma visita.

As comemorações de aniversário do Sr. Anísio eram acontecimentos do bairro, e que mobilizavam uma pequena multidão de filhos, netos e outros parentes (iam até as criancinhas de colo, em algum momento sempre fotografadas com ele), amigos e admiradores de Salvador, além dos que vinham do interior do estado, e vizinhos; havia sempre missa festiva na igreja do bairro e jantar em sua casa. Uma das presenças constantes, a cada ano, era o amigo de cujo registro de nascimento ele foi testemunha, no interior - que proclamava isso com orgulho -, e estava muito mais "velho" e inseguro das pernas que Sr. Anísio.

Este considerava, entretanto, e mais além das perdas referidas dos seus iguais geracionais, que não é bom ser velho, "porque os filhos é quem manda, eu não tô mandando mais em nada. Eu vou fazer uma coisa, eles dizem: 'Não fazer isso, não. Fazer outra coisa.' Eu acho ruim por isso, mas vai vivendo".

O desejo de conhecer D. Januária veio da contemplação do seu retrato em um jornal: sorriso aberto, abraçando o violão. Em abril de 2002, aos 108 anos, a primeira entrevista, onde ela declarou: "Eu me sinto muito bem e canto em verso e prosa". Realmente, na época tocava violão, gravara uma fita e estava iniciando um livro de memórias, que veio a lançar em maio de 2004, na festa de seus 110 anos. Na comemoração do seu $112^{\circ}$ aniversário que acompanhamos, como sempre com missa festiva, continuava alegre, conversando e interessada nas pessoas. Morreu alguns meses depois.

Naquela primeira entrevista, e de certo modo contraditoriamente com a sua usual animação, reclamava da velhice, porque, apesar de ter boa memória (era uma ativa contadora de histórias), seu corpo a limitava - usava cadeira de rodas, sua voz estava rouca, queixava-se de fastio, dificuldade para ler ("as letras embaralham") e para escrever - "as letras saem da linha". Também os dedos doíam quando tocava o violăo.

De cor clara, simpática, sorriso constante, em contraste com as queixas. Viúva há longos anos, nunca trabalhou fora, mas "Trabalhei dentro de casa, trabalho puxado, porque nove filhos!". Um 
salário mínimo de pensão, orçamento complementado pelas filhas. Os três filhos homens já haviam morrido. Vivia com a filha mais moça, que a rodeava de cuidados: "A minha vida aqui, ela é a responsável por tudo. Eu era mãe, agora sou filha (riso)". "E ela a chefa da casa, é ela quem manda, é ela quem resolve...".

Durante a doença e após a morte do marido, teve o apoio decisivo do filho mais velho, a quem sempre elogiava muito e cuja morte lamentava, a ponto de em certo momento declarar: "Para mim o mundo morreu, não tenho mais alegria pra nada". Apesar dos cuidados constantes dessa filha, de telefonemas e visitas nos fins de semana das outras filhas (idades entre 84 e 72 anos), dizia sentir-se só. Ainda que contando também com cuidados e atenção da empregada, queixava-se quando a filha saía: "Aí eu sinto muita solidão, viu? Eu sinto, porque ela precisa sair e a moça fica trabalhando lá dentro e ela é muito calada. Nem ao menos ela canta!". D. Januária dizia que para passar o tempo "tenho sempre que inventar alguma coisa". "Só fico alegre quando tem gente, meus filhos, minhas amigas".

Apesar das queixas, referia ter muitas amizades boas: "Faço aniversário e todo mundo vem". As filhas e os amigos realmente a procuravam bastante.

Comentava a relação com a família: "É boa, é ótima". Não apenas os filhos, mas também os netos iam sempre visitá-la, e quando nasciam os seus filhos, levavam para a avó conhecer: "Alguns tiram fotografia comigo e com a criança". Raramente saía de casa: "Dou trabalho porque tem que tirar da cadeira e botar no carro, essa coisa toda". Por isso, muitas vezes, desistia de sair.

Em casa, ficava no quarto, principalmente. Dizia ter vontade de trabalhar, não para ganhar dinheiro, mas queria fazer "qualquer coisa que os outros façam e que eu não posso fazer". Resignada, reconhecia seus problemas de saúde, "da idade", como dizia: "Eu estou assim e não posso fazer nada”.

Tornaram-se especialmente elucidativos das relações de família entre idosos os depoimentos da filha Hilda, de 70 anos, que era a sua cuidadora, ao mesmo tempo legítimo exemplo da "geração-pivô" (Attias-Donfut, 1995; Delbes \& Gaymu, 1993): apoiando e cuidando da mãe centenária, apoiando financeiramente o filho descasado, de 32 anos ("Casou sem ter ainda condições de casar") e pagando a pensão alimentícia do neto de 5 anos, que morava com a mãe. 
Hilda fazia algumas queixas da mãe, por ser "muito teimosa". Eram os desgastes do dia a dia. O problema de audição de D. Januária, por exemplo, trazia transtornos: "A gente fala uma vez, ela não ouve. Fala uma segunda vez, ela não ouve. Fala a terceira vez, quer dizer, a voz já sai diferente, né? Quando a gente fala mais alto, sai assim aquela voz forte, aí ela diz 'Isso é brutalidade, não precisa gritar'. Aí eu digo: Mas eu não estou gritando, eu só estou falando mais alto".

Arrolava os cuidados que prestava: "Precisa que eu dê banho, eu faço a higiene, levo ao sanitário, assear, lavar as mãos, levar ela ao banheiro". Mas reconhecia o esforço da mãe: "Também ela se ajuda muito, ela tem muita força de vontade".

Considerava sempre dar o melhor de si para a mãe e isso nem sempre ser reconhecido: "Eu sei que eu faço o que posso, e às vezes o que eu não posso eu faço, mas não sei, nem sempre há satisfação nas minhas irmãs (...) sugestôes muitas, mas ajuda, nenhuma".

Deixava, por vezes, aflorar o ciúme, contando que, quando a irmã que mora no interior do estado vinha a Salvador e ficava na sua casa, as outras irmãs reclamavam e ela dizia "Eu vim pra ficar com mamãe". "Fica aqui e toca violão com ela, porque aquela ali [faz gesto em direção a D. Januária] é animada e ela também é muito animada". E desta D. Januária não reclamava nada...

Liberava outra ponta de ciúme em direção ao filho na relação com a avó - mais um caso do clássico acordo entre geraçóes alternadas: "Ela gosta muito dele, ele também gosta muito dela; ele parece gostar mais dela que de mim, é 'voinha' pra lá, 'voinha' pra cá...".

O filho, Gustavo (32 anos), é músico. Falou com carinho sobre D. Januária: "A minha avó é legal, né, aquela pessoa ali, de idade avançada, mas forte, né, firme e tal". Revelou que veio dela o seu interesse pela música: "Eu via a minha avó com o violãozinho dela, ali, tocando aquelas músicas antigas, e eu ficava ali, encantado". Considerava a avó “(...) uma pessoa jovem. Eu acho que o que deixa ela viva é a vontade de continuar vivendo".

Após a morte de D. Januária mantive o contato com Hilda, como será visto adiante. Sua condição geracional de pivô rendeu boas observações e revelações.

O primeiro contato com D. Guiomar foi em 2002, quando ela estava com 98 anos. Na fase atual da pesquisa (referente ao quarto 
projeto de pesquisa), ${ }^{2}$ ainda em andamento, mantemos o contato com ela e já entrevistamos boa parte da sua família. D. Guiomar, apesar de vários problemas de saúde - usa marca-passo, sofreu um acidente e anda com um pouco de dificuldade, usa aparelho auditivo e enxerga só de um olho -, apesar de tudo isso, transmite um vigor impressionante e é muito animada. Tem ótima memória e impõe-se naturalmente como autoridade na família.

Viúva, com 7 filhos, 26 netos e 42 bisnetos, informou quando da primeira entrevista. Teve vida profissional ativa - secretária de importante instituição educacional do estado -, que só interrompeu com a aposentadoria compulsória.

Conta que uma funcionária da instituição comentou: "Mas a senhora vai se aposentar?! Viva, assim? Com esse trabalho todo perfeito?”. E ela: "Eu não vou trabalhar de graça para o governo!". Mas comenta: "Ai que saudade eu tenho!".

Tanta dedicação só lhe rendeu um salário mínimo de aposentadoria: mora em casa própria, há mais de 50 anos, em bairro popular. Sente-se bem lá e é visivelmente querida pela vizinhança. Uma filha viúva mora com ela e sustenta a casa. Uma neta, filha dessa filha, mora no andar superior, com o marido e o filho criança.

D. Guiomar conta que até poucos anos atrás fazia de tudo em casa. Foi deixando, "mas eu ainda trabalho (...) minha roupinha eu lavo". Gosta de passear e vai a restaurantes com filhos e netos. Considera a relação com a família "a melhor possível" - o que é realmente perceptível.

Sobre a velhice comenta que "há idosos abusados e já tem outros que são alegres, então eu pertenço a este lado, o lado dos idosos alegres, porque eu nunca estou contrariada...". Gosta de ouvir música e de cantar, e já tocou violino. Conta que de vez em quando fica cantando no quintal e é aplaudida pelos vizinhos.

Seu centenário, em 2004, foi comemorado em um amplo espaço de eventos, com muitas gerações presentes. A aniversariante, feliz, sorria e cantava enquanto dançava com um dos filhos, Aristóteles, que, exceção como filho homem, presta constante assistência à mãe e a visita todos os dias. Dançou também com seu médico, que a beijou, carinhosamente, na testa. Ao final da festa, ela falou ao microfone, agradecendo a todos, filhos, netos, bisnetos, parentes e amigos, pela presença. 
Sobre o que mais deseja, revela: "Peço a Deus que os dias passem e não me jogue na cama, me deixe em pé até o meu dia” (preocupação geral entre os velhos ativos em toda a parte).

Quando da primeira entrevista, D. Guiomar comentou que o período mais feliz de sua vida talvez fosse aquele mesmo, "Porque os filhos estão criados". Agora vive um período difícil, embora sempre demonstre força. Quando completou 102 anos, em janeiro de 2006, não quis muitas comemorações, como já não vem querendo desde então, porque naquele momento o filho mais velho, de 78 anos, estava internado com um derrame cerebral e a filha mais velha, atingida pelo mal de Alzheimer, estava pior. Em conversa, desabafa: "Eu não me conformo, minha filha. Não adianta que eu não me conformo. Ele tá com 78 anos, internado. Eu com essa idade tava nova em folha. Aliás, eu com 94 anos dizia que tinha 49!". E sobre a filha doente: "Fico imaginando quando eu fizer 'a minha viagem', como é que fica Mercês? Ainda não me conformei com a situação dela. Minha filha mais velha... achei que ela é que ia cuidar de mim".

Mesmo naquela circunstância, foi muito visitada e recebeu muitos telefonemas.

Logo após o referido aniversário, o filho faleceu. Ela ficou entre inconformada e aliviada, porque ele já não estava sofrendo, confidenciou. É o segundo filho que perde. "Já tenho 102 anos e estou aqui, saudável! Só tenho medo de deixar essa aí doente, coitada."

Numa das visitas seguintes da equipe da pesquisa, contou que estava muito infeliz em razão dos problemas de saúde dos filhos. "Tenho medo de 'ir embora' e deixar Mercês sozinha nessa situação. Ela não lembra de nada e às vezes só obedece a mim”.

Dona Guiomar é, entretanto, uma pessoa de grande presença, forte e simpática. É conhecida e estimada por toda a vizinhança. Apesar do seu recente retraimento em relação a comemorações, teve o aniversário seguinte obrigatoriamente alegre, comemorando os seus 104 anos com um café da manhã festivo organizado pelos vizinhos.

$\mathrm{O}$ que é mais um fato que reforça minha observação e o repetido registro de como esses centenários que tenho encontrado têm-se revelado geralmente objeto de admiração e carinho mesmo dos que não participam do seu cotidiano imediato, como a comunidade do bairro. Carinho e admiração que são fortemente expressos, sobretudo, 
pela geração dos netos. No caso de D. Guiomar isso aconteceu com intensidade, do mesmo modo que em relação a D. Januária, como foi visto, e a vários outros centenários acompanhados na pesquisa. Por exemplo, Cristina, de 40 anos, neta de D. Guiomar, falando sobre a condição de jovem, curiosamente reportou-se à avó, comparando-se com ela: "Ser jovem é estar aberta às coisas do mundo, às pessoas. Minha avó, eu considero uma pessoa com a mente muito jovem, ela não se escandaliza com nada, ela acolhe tudo que é novo, ela é referencial de juventude; em termos de cabeça, ela é muito mais jovem do que eu, pois sou muito acomodada".

Falando sobre idosos, retorna naturalmente à avó: "Um idoso como minha avó é um dom grande, todas as vezes que eu vou lá eu volto renovada, pois ela me diz cada coisa que me surpreende. Ela aglomera a família em torno dela”.

Continuamos a visitar D. Guiomar regularmente e a participar das festas em seu aniversário. Nos últimos anos ela conta com o apoio de uma acompanhante, cuidadora profissional, porém diante de sua força de vida não tenho como referir um pivô na família de D. Guiomar que não seja uma figura excepcional que é ela própria.

Enquanto os centenários constituem geração demograficamente precisa, apesar de uma extensão desse segmento de idade já se delinear, no tempo e na designação, na forma de "supercentenários" - como referência àqueles maiores de 110 anos -, a geração intermediária, ou geração-pivô (Attias-Donfut, 1993, 1995, 2004; Delbes \& Gaymu, 1993; Hareven \& De Gruyère, 1999), é de definição relacional e de situação. Porque as idades de intermediação e apoio constante entre geraçôes variam de acordo com a sequência temporal, demográfica e o dinamismo das relações do grupo de parentesco. Podem se situar na meiaidade, tanto quanto na velhice “jovem” e até um pouco além, porque em época de longevidade crescente todas as presenças etárias têm vez. Embora seja mais comum pensar-se a geração intermediária em torno dos 50 anos (Arfeux-Vaucher, 2003; Delbes \& Gaymu, 1993), certamente correspondendo à representação tradicional das famílias de três gerações, com a crescente longevidade atual ensejando o desdobramento das famílias em quatro e até cinco gerações simultâneas, o pivô frequentemente é mais que cinquentão. Ou melhor, mais que cinquentona... Porque a situação de gênero, no caso, é que pouco varia - são majoritariamente mulheres que, bem além do fato de viverem mais que 
os homens, têm o "destino" tradicional de suporte familial. Por isso é importante que seja lembrado que muito da solidariedade intergeracional existente se realiza à custa do esforço emocional e do trabalho não remunerado das mulheres.

Como fenômeno social novo em escala ampla - tanto quanto pela sua imprecisão de lugar cronológico e social -, a geração intermediária é objeto sempre de referências muito breves - por exemplo, Delbes e Gaymu (1993) -, embora estas já se amiudem, denotando um início de preocupação social com essa situação de apoios familiares pressionante, que constitui ao mesmo tempo um elemento ou uma consequência da condição analisada como solidariedade pública entre as gerações (AttiasDonfut, 1995).

Essa geração intermediária corresponde, em grande parte, à dos atualmente classificados como "idosos jovens". Aqueles que vivem um dinamismo inédito na história e ajudaram a construir uma nova imagem, mais atuante e atraente, da velhice, na sociedade atual (Britto da Motta, 1999b; Debert, 1994; Peixoto, 1997), particularmente visíveis por meio dos multirreferidos "programas para a terceira idade" e, em momentos cruciais, do movimento dos aposentados. Programas e movimento que, indo, mesmo quando não intencionalmente, muito além de seus interesses e propostas iniciais de lazer "produtivo" e de ação política imediata, constituíram-se em agências ressocializadoras, em direção a uma condição de maior dinamismo social de uma geração, no interior da qual se destacou uma significativa mudança na condição de gênero das mulheres idosas. Sentindo-se elas então mais livres e satisfeitas na vida cotidiana e de família, identificadas com suas "colegas" dos grupos de "terceira idade" (Britto da Motta, 1999b) e iniciando um aprendizado político nas associações de aposentados (Azevedo, 2010).

Essa "geração-pivô" pode desdobrar-se ainda em um outro segmento geracional um pouco mais velho; pode corresponder a uma "quarta idade" - 80, 80 e alguns anos -, cuidando de uma "quinta idade" - aqueles em torno de 100 e mais anos.

Esse amplo segmento intermediário, tão desdobrável, portanto, em idades e diferentes experiências na qualidade de filhos, por mais dinâmicos e ao mesmo tempo controladores que muitos sejam sobre seus pais "velhos-velhos", também termina por sofrer restrições no ir e vir. Principalmente em se tratando de mulheres. 
Nesta fase, tão incipiente ainda, dessa discussão temática, tem-se exposto uma espécie de preocupação argumentativa com o "peso" ou a dificuldade maior que existiria, agora, no cuidado com os pais muito idosos, porque se tem um número menor de filhos (Delbes \& Gaymu, 1993). Ainda não é o argumento principal. Em primeiro lugar, para a geração dos hoje muito idosos ainda não se constataria uma redução sensível no número de filhos, pelo menos em países do Terceiro Mundo. Além disso, o que as minhas pesquisas têm mostrado é que sempre há um filho - ou melhor, e significando clara questão de gênero -, uma filha que fica "escolhida” para cuidar do idoso, ao passo que os outros filhos frequentemente se omitem, portando-se como visitas eventuais, e não raro críticas.

Há sempre desabafos sobre renúncias que realizam, relatos de impossibilidades ou dificuldades de passeios ou distrações, seja porque os mais velhos não gostam, seja porque não podem sair. Há - nem sempre leves - obrigações financeiras, também. É o caso, que encontrei em pesquisa, de Hilda.

Hilda, setentona, é a referida filha mais moça de D. Januária, de 112 anos, cujos outros filhos sempre moraram em suas respectivas casas. É a filha que morava com a mãe e a assistia, em sua velhice lúcida, mas com movimentos já dificultados. Ao longo da entrevista, e sobretudo em conversas subsequentes, expressou mágoas. Queixava-se das irmãs, ausentes, que não assumiam qualquer responsabilidade - tanto em cuidados como financeiramente - em relação à mãe, mas queixavase também desta, de suas "teimosias" e "desobediências" em querer comer "o que não pode" e de sair da cadeira de rodas sem ter alguém por perto que pudesse ajudá-la. Lamentava muito, também, a não aceitação, da parte de D. Januária, do companheiro com quem mora, que parecia tratá-la muito bem.

Criticava seguidamente essa ausência das irmãs, o que resultaria em solidão para a mãe, e revelou renúncias que realizava, para que essa solidão não fosse muito grande. Ao mesmo tempo, tinha ciúmes pelas "festas" que a mãe fazia quando as outras irmãs a visitavam, ao contrário do que costumaria fazer em relação a ela, Hilda, em uma relação desgastada pelo cotidiano.

Hilda revelou, ainda, como uma certa queixa, que também dependiam dela, em grande parte, um filho de 32 anos e um neto de 5 anos. Especificava: pagando plano de saúde para os dois e ainda dando 
"uma ajudazinha" ao filho: "Meu filho (...) ainda depende de mim, porque casou sem ter condição de casar, teve esse filho, já separou, mas tem que dar a pensão do menino (...)".

O dilema de Hilda poderia ser expresso nas palavras de Hareven e De Gruyère (1999, p. 18): "El deseo de cumplir com las expectativas de sus padres e al mismo tiempo inpulsar a sus hijos se sumó al conflicto generacional como consecuencia de sus obligaciones hacia ambos".

Muito ativa, pinta, faz artesanato e frequenta uma Faculdade para a Terceira Idade. $\mathrm{O}$ marido e a mãe reclamavam que ela só vivia saindo. D. Januária insistia: "Só vive na rua, só vive na rua". E ela respondia: "Os velhos agora vivem na rua, não ficam em casa nem a pau”.

Suas saídas, explicava, eram à tarde; de manhã havia lides domésticas (comentava que a empregada não era eficiente) e o ritual do banho da mãe (repetia: "Não conto muito com minhas irmãs."). Queixava-se, sempre e longamente, mas com algum humor, e, apesar das referências a saídas, relatava impossibilidades de passeios e distraçóes, porque D. Januária não gostava de sair e os domingos se arrastavam, todos (ela, o marido e a mãe) "no quadrado" (do apartamento), sem saber o que fazer. Desabafou: "Eu faço o que posso (...) e às vezes o que não posso eu faço, mas não sei, nem sempre há satisfação nas minhas irmãs, 'porque eu acho que você deveria isso, deveria aquilo', sugestóes muitas, mas ajuda nenhuma...”.

Apesar de tantas queixas, considerava que a mãe e ela se davam bem e que esta cooperava no que podia, em relação aos cuidados de que necessitava.

Um tempo depois da morte de D. Januária fomos visitar Hilda. O cenário então era outro: no apartamento continuavam apenas esta e o companheiro. Ela comentou que o apartamento "está vazio". Mantém "o quarto de Gustavo", o filho casado que estava separado, e "o quarto de mamãe...”. Hilda pareceu serena. Mostrou novas peças do seu trabalho artesanal, falou sobre os talentos artísticos da família e chegou à morte de D. Januária, logo após o aniversário de 112 anos. Para o sepultamento - cerimônia que descreveu como tocante - "veio todo mundo".

Apesar da aparente serenidade, demonstra estar abalada com a morte da mãe. Não sente vontade de sair de casa para se divertir e não conseguiu assistir à gravação da última festa de aniversário de D. Januária. Queixa-se de solidão. "Agora é só eu e meu marido. Ninguém 
mais vem aqui, porque as visitas todas eram para ela. Ela já me dizia isso, 'Todo mundo que vem aqui é para me ver'. Mas só agora caí na real”.

Depois de um silêncio, continua: "Agora sei o que mamãe passou. Ela sempre se queixava de que eu saía demais e eu saía mesmo, até três vezes por dia; mas agora eu não tenho mais vontade de sair". Fala também do companheirismo entre as duas, de verem a novela juntas, e até dos próprios atos de cuidado (dar remédio, trocar fraldas) como atuação juntas e companheirismo.

Em contrapartida, o filho reconciliou-se com a esposa, voltaram a morar juntos e ela vê pouco o neto. O filho não a visita e esse afastamento a leva a temer também pelo seu futuro de idosa: como a mãe, irá necessitar do apoio da família - contará com o filho?

Neste ponto registro o interesse de uma reflexão próxima sobre o futuro desta geração dos meia-idade e "idosos jovens" em termos desse "contrato geracional" (Bengtson \& Achenbaum, 1993) que, lembram Attias-Donfut e Arber (2000), sempre foi baseado em um "contrato de gênero", pelo qual as mulheres entram como cuidadoras.

Um "pivô" mais jovem e uma relação menos afetiva entre as gerações podem ser exemplificados pelo caso de Dalva. Que talvez já demonstre um certo afrouxamento de laços das gerações mais novas de filhos em relação a seus pais de idade mais avançada, que Hareven e De Gruyère (1999) começam a relatar. E que Attias-Donfut (2004) também identifica, mais recentemente e com maior incisividade.

Dalva, de 51 anos, também é a filha mais nova de D. Davina, 81 anos. Moram em uma casa ampla e confortável, com jardim e piscina, com o marido e os filhos de Dalva. O outro filho de D. Davina mora em outro estado, mas veio estar com ela recentemente. D. Davina era bem ativa em 2002, quando da primeira entrevista - passeava, viajava, frequentava um curso "para terceira idade". Entretanto, desenvolveu problema ortopédico grave, sofreu cirurgia e tornou-se limitada a uma cadeira de rodas. Entristecida, mudou de humor; tornou-se bastante solitária afetivamente, por só contar com a presença - ininterrupta - e os cuidados de profissionais da saúde. A filha montou uma eficiente organização "burocrático-administrativa" em torno da mãe, com esses profissionais, mas não demonstra ter participação direta e afetiva nela. Trata a mãe ao mesmo tempo com distância e brusquidão (de certo modo, a filha adolescente também trata Dalva assim). Conseguiu-se observar que, 
reativamente, D. Davina "vinga-se" daquela impessoalidade demonstrando mais fraqueza e impossibilidades de movimentos quando está na presença da filha... Entrevistada recentemente, esta falou sobre suas atividades profissionais pós-aposentadoria, porém se mantendo muito reticente quanto a questôes de orçamento familiar, que, apurou-se, conta com ponderável contribuição de D. Davina:

"Prefiro não detalhar, porque são coisas complexas (...). Ela já é bem idosa, então ela só é cuidada, mas as coisas financeiras a gente divide muito (...)".

Sobre as suas relações em família, avalia:

“(...) aqui em casa eu me dou bem com todo mundo, não tem problema, não. Com a mãe sempre tem discussão, que é normal, né, uma pessoa idosa, né, sempre tem discussão".

Sobre a velhice da mãe:

"É bom de um lado e um pouco, assim, desgastante do outro, né; tem toda a felicidade de você ter uma mãe ainda, né, nesta idade, e ao mesmo tempo tem essa parte do trabalho que as pessoas idosas necessitam, precisam, né, dão, aliás...”.

Instada a falar sobre a situação ou a participação da mãe no cotidiano da família, declara:

"Olhe, a família faz tudo para ela participar, mas na realidade a participação dela é um pouco repelida pela família porque ela só quer participar das preocupaçôes; de horário, só pensa em coisas... que vai ter um acidente, que as pessoas vão chegar... sempre isso. A participação que a família gostaria e queria que ela tivesse é de dividir alguma coisa, ou dividir alegria, ou conversar, ou até trabalho, se fosse o caso, né, diversão e tal, e não essa preocupação que ela tem, eterna, né, sempre, que é fruto da carência (...). Acompanhamento psicológico toda pessoa idosa necessita, porque eles ficam carentes, né, então necessitam. O acompanhamento psicológico que eles necessitam não é nem acompanhamento psicológico, é companhia mesmo, que eles são carentes e precisam sempre, né. Só que é uma questão muito difícil de ser resolvida, porque o ser humano se adapta melhor, ele fica mais feliz, se ele tiver [companhia] na faixa etária dele, e você não pode deixar um monte de pessoas com 80 e tantos anos juntos, só, pessoas tomando conta junto, né, então é mais difícil, né”. 
Solicitada que avaliasse o "peso" dos seus papéis no grupo familiar, para ela, que se divide pouco entre os seus familiares, a resposta veio simples, "matemática": "No momento o mais importante é o de mãe, pois se eu tenho três filhos e só tenho uma mãe...”. Entretanto, "corrige" a proporção ao final: "Na realidade... os dois são importantes".

Moldura e ao mesmo tempo fundo desse quadro é a família multigeracional contemporânea. A família sempre como espaço fundamental e modelar das relações de gênero e entre gerações (Britto da Motta, 1998), mas apresentando a peculiaridade de contar com a presença simultânea de várias geraçôes e de modo mais duradouro do que em qualquer outra época da História. A ponto de que já se encontrem, com bastante frequência, essas famílias estendidas em até quatro e cinco gerações simultâneas, e unidades domésticas onde coabitam duas a três dessas geraçôes. Destacando-se, entre elas, os centenários com seus claros "segredos" e, ativa e à espera de pesquisa sistemática, a geração-pivô.

\section{Recebido em maio de 2010 e aprovado em junho de 2010.}

\section{Notas}

1. Os projetos "Os velhos mais velhos" (2000 a 2001); "Relações entre gerações: pais e filhos idosos" (2002 a 2004) e "Relaçōes de gênero e entre geraçôes: pais, filhos e netos" (2005 a 2007) contaram com o apoio do CNPq (Bolsa PQ), do PIBIC e do PIBIC/FAPESB (Bolsa IC). Participaram das várias fases os seguintes estudantes: Patrícia Schramm Andrade, Carla Pellegrino, Ulisses Oliveira Amorim, Zilmar Alverita da Silva, Fabiana de Santana Medeiros, Hugo Lessa Gama, Carolina Santana de Souza e Jeane Rangel.

2. Projeto "Personagens geracionais na família contemporânea: centenários e pivôs" (2008 ainda em andamento); também, com bolsas PQ e PIBIC/FAPESB, com a participação das estudantes Clarissa Paranhos Guedes, Elaine de Carvalho Lima, Liv Lobo e Iracema Sousa de Medeiros Costa.

\section{Referências}

ARFEUX-VAUCHER, G. Les familles à cinq générations: entre plaisir et souffrance. Recherches et Prévisions, Paris, n. 71, p. 5-19, mars 2003.

ATTIAS-DONFUT, C. Un jeu entre générations. Informations Sociales, Paris, n. 30, p. 112-117, 1993. 
ATTIAS-DONFUT, C. Le double circuit des transmissions. In: ATTIASDonfut, C. (Org.). Les solidarités entre générations. Paris: Nathan, 1995. p. 41-81.

ATTIAS-DONFUT, C. Sexo e envelhecimento. In: Peixoto, C.E. (Org.). Familia e envelhecimento. Rio de Janeiro: FGV, 2004. p. 85-108.

ATTIAS-DONFUT, C.; ARBER, S. Equity and solidarity across the generations. In: Arber, S.; AtTIAs-Donfut, C. (Ed.). The myth of generational conflict. London; New York: Routledge, 2000. p. 1-21.

AZEVEDO, E.L. Um palco de múltiplas vozes: a nova invenção dos(as) idosos(as) em luta pela cidadania. 2010. 277f. Tese (Doutorado em Ciências Sociais) - Faculdade de Filosofia e Ciências Humanas, Universidade Federal da Bahia, Salvador.

BENGTSON, V.; ACHENBAUM, W.A. (Ed.). The changing contract across generations. New York: Aldive de Gruyter, 1993.

BOURDIEU, P. Coisas ditas. São Paulo: Brasiliense, 1990.

BRITTO DA MOTTA, A. Reinventando fases: a família do idoso. Cadernos do CRH, Salvador, v. 11, n. 29, p. 69-88, jul./dez. 1998.

BRITTO DA MOTTA, A. As dimensões de gênero e classe social na análise do envelhecimento. Cadernos Pagu, Campinas, n. 13, p. 191-221, 1999a.

BRITTO DA MOTTA, A. Não tá morto quem peleia: a pedagogia inesperada nos grupos de idosos. 1999b. 283f. Tese (Doutorado em Educação) - Faculdade de Educação, Universidade Federal da Bahia, Salvador.

BRITTO DA MOTTA, A. Idosos na sociedade brasileira no limiar do século XXI. In: Gico, V.; Spinelli, A.; Vicente, P. (Org.). As Ciências Sociais: desafios do milênio. Natal: EDUfrN-PPGCS, 2001. v. 1, p. 620-633.

BRITTO DA MOTTA, A. Espaço doméstico e geraçôes: disputas veladas e renúncias ambíguas. Trabalho apresentado no 11. Encontro de Ciências Sociais do Norte e Nordeste. Aracaju, Universidade Federal de Sergipe, ago. 2003. (CD-ROM). 
BRITTO DA MOTTA, A. Sociabilidades possíveis: idosos e tempo geracional. In: Pеiхото, C.E. (Org.). Familia e envelhecimento. Rio de Janeiro: FGV, 2004. p. 109-144.

BRITTO DA MOTTA, A. A juvenilização das idades. Trabalho apresentado no 13. Encontro da REDOR, Recife, nov. 2006 a.

BRITTO DA MOTTA, A. Cem anos e um segredo. Trabalho apresentado na 25. Reunião Brasileira de Antropologia, Goiânia, 2006b.

BRITTO DA MOTTA, A. Ter cem anos no Brasil. Trabalho apresentado no 52. Congresso Internacional de Americanistas, Sevilha, 2006c.

BRITTO DA MOTTA, A. The ages of ageing. Trabalho apresentado no 1. ISA Forum of Sociology, Barcelona, 2008.

CAMARANO, A.A. Muito além dos 60. Rio de Janeiro: IPEA, 1999.

CAMARANO, A.A. (Org.). Os novos idosos brasileiros, muito além dos 60? Rio de Janeiro: IPEA, 2004.

DEBERT, G.G. Gênero e envelhecimento. Revista de Estudos Feministas, Rio de Janeiro, v. 2, n. 3, p. 120-128, 1994.

DELBES, C.; GAYMU, J. Les familles à quatre générations. Informations Sociales, Paris, v. 32, p. 8-12, 1993.

HAREVEN, T.; DE GRUYERE, A. La generación de en medio: comparación de cohortes de ayuda a padres de edad avanzada dentro de una comunidad estadounidense. Desacatos, Revista de Antropología Social, México, n. 2, 1999. Disponível em: <http://redalyc.uaemex.mx/redalyc/ src/inicio/ArtPdfRed.jsp?iCve=13900203>. Acesso em: 25 abr. 2009.

LENOIR, R. L'invention du troisième age: constitution du champ des agents de gestion de la vieillesse. Actes de la Recherche in Sciences Sociales, Paris, n. 26, p. 57-82, 1979.

MANNHEIM, K. O problema das gerações. In: Mannheim, K. Sociologia do conhecimento. Porto: Res, [19-]. p. 115-176. (edição original 1928)

PEIXOTO, C.E. Histórias de mais de 60 anos. Revista de Estudos Feministas, Rio de Janeiro, v. 5, n. 1, p. 148-158, 1997. 
PEIXOTO, C.E. Aposentadoria: retorno ao trabalho e solidariedade familiar. In: Peixoto, C.E. (Org.). Familia e envelhecimento. Rio de Janeiro: FGV, 2004. p. 57-84.

SIMÕES, J.A. Provedores e militantes: imagens de homens aposentados na família e na vida pública. In: Peixoto, C.E. (Org.). Família e envelhecimento. Rio de Janeiro: FGV, 2004. p. 25-56. 